\title{
The Unemployed as "Others" in Welfare Journalism
}

\author{
Mika Renvall \& Pertti Vehkalahti
}

The Finnish recession in the 1990's was the deepest economic crisis in any developed, industrialised economy since the Second World War. It took place in the kind of welfare state which Gösta Esping-Andersen has labelled 'Nordic' or 'social democrat' (EspingAndersen 1990, 1999), the characteristics of which are, among others, high level of employment and labour market participation rate, high level of social security, low income differences and strong but moderate trade unions and left wing parties. 90's crisis has been interpreted to be a turning point in the path of the welfare state development. Finnish welfare state has been loosing some of its discernible Nordic characteristics and Finnish welfare politics have taken a neo-conservative turn of a kind (Hänninen 1998, Julkunen 2001, Lehtonen \& al. 2001).

In this paper we focus especially on the relationship between the alleged neo-conservative turn in Finnish politics and the newspaper stories about the unemployed. We describe four politically loaded and recurring news narratives about the unemployed how the unemployed are represented in them and what kind of consequences these representations might have. These narratives include the story of the welfare abuser, of 'the work shy', of the exemplary job-seeker and of the 'activation' of the unemployed.

The consequences of narratives must be assessed against some frame of reference. Here we consider, what kind of impact such narratives might have for public life. Following Habermas we take the political public sphere, where public life takes place, to be the sphere "between" the state and the private sphere. According to Habermas, the public sphere could act as a "warning system" signalling the political system that some problems have become aggravated, and as an "amplifier" which is able to thematise and dramatise the detected problems in an influential way. $(1996,359)$. The social formations that constitute the ideal public life are not "crowds", which are characteristically constituted by agitation, but "publics". Publics are based on differing interests that must be adjusted to each other. Such a public must be able to think and discuss in a reasonable manner. (see V. Pietilä 1999, 7-8)

\section{Moral Panic and Social Responsibilities}

We take as our starting point the finding of Peter Golding and Sue Middleton, (Golding \& Middleton 1982, see also Hall 1992, Clarke \& Newman 1997, Julkunen 1993, Roche 1992) that neo-conservative politics of Margaret Thatcher were accompanied by a certain form of discourse used in order to produce 'moral panic' about welfare abuse, and 
suggest that such a discourse can be taken as a paradigmatic example of a conservative discourse about the unemployed. The gist of such discourse is to represent the poor and their helpers as immoral or even criminal. Typically such discourse picks up court cases of poor accused of welfare abuse. These examples are used to make general claims for instance about the demoralising effects of welfare policies. Conservative speakers call for stricter control and less generosity, while more leftist voices are subdued by accusing them of speaking on behalf of criminals and crime. Indeed, it was found (see Renvall $\&$ Valtonen 1999) that the welfare abuse - narrative did become more and more prominent in the Finnish media during the 1990's, especially in the last years studied, 1997 and 1998. It was promoted by some top conservative politicians, and some metaphors typical to the British case were invoked such as the claim that only 'the tip of the iceberg' of welfare abuse is visible. The narrative was, however, also challenged in the media by social workers, researchers and also journalists themselves. The narrative never achieved any unchallenged acceptance in the public debate.

Some characteristics of the neo-conservative image can be discerned in the following cartoon taken from a story in Aamulehti (21.7.1997. Figure 1). In the cartoon we see a character who, first of all, is young - young people obviously are one favourite group of scapegoats in our society and are often associated with subcultures, violence, drugs etc. $\mathrm{He}$ is also dressed in a way that refers to some youth subculture. He is surrounded with equipment both expensive and leisurely. He is, nevertheless, not looking satisfied but rather aggressive and ready to ask for more. Interestingly, the front page photograph of the same story, displaying various badges distinctive of certain youth subcultures, provoked a letter to the editor (AL 25.7.1997), in which a young writer ventured to deny that wearers of such badges are welfare abusers. Such a spontaneous attempt to dissociate the two images serves to show how such images work - abuse-narrative presses one to try to present oneself as 'different but good' in order to dissociate oneself and one's subculture from the 'bad'.

Figure 1.

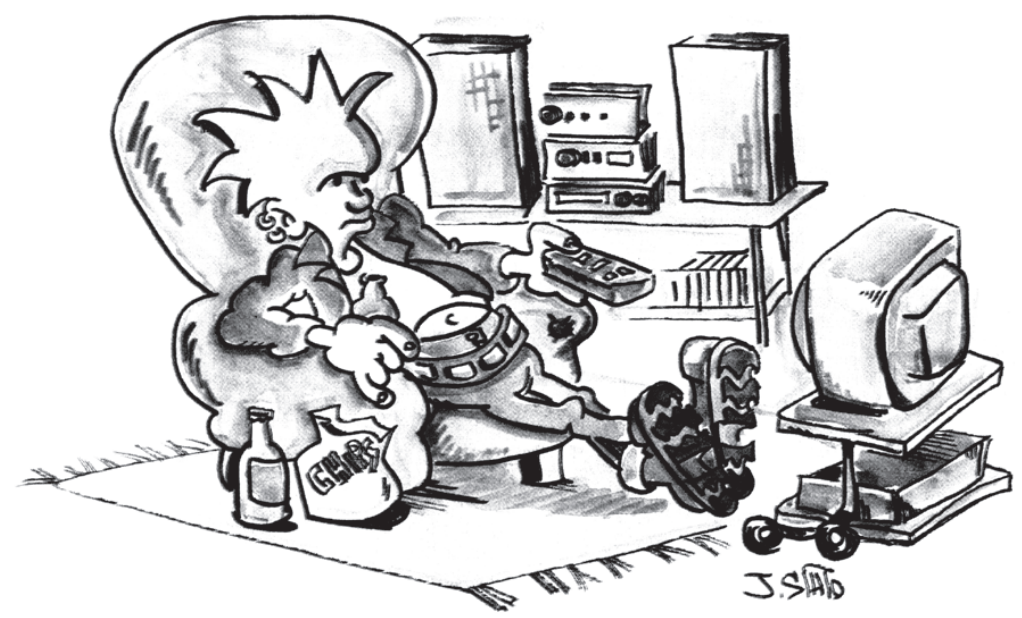

Miksi töihin? Jos saman rahan saa työtä tekemättäkin, voi ajatus kotiin jäämisestä houkuttaa. 
Roche (1992) has pointed out, that, in thinking about welfare, the essence of neoconservatism lies in emphasising social responsibilities of citizens instead of social rights. In the news, such as the example above, social responsibilities are emphasised at least in three ways: through individualisation, through moral indignation and through a critique of the income distribution policies of the state. Individualisation refers to the representing of the problems of the unemployed as their personal and individual problems, not as social or structural problems which should be taken care of by the state. In building moral indignation the well known "Us" vs. "Them" scheme is applied, where certain "others" are pointed out as "offenders" of various kinds. The welfare state is criticised for hindering economic growth and maintaining irresponsible behaviour. The more or less explicit aim underlying the use of such discourse is often to cut the welfare state.

It is obvious that the image above is about socially irresponsible behaviour. Moral narrative works here on two levels: first, it warns one, that since the deception is exposed and moral indignation is, presumably, aroused, the abuser will be punished - second, it includes a plea that in order not to hurt oneself as well as the whole community through acts which undermine social solidarity the abuser ought to change his or her ways. In the latter sense the narrative is emphasising the "internal good" (see MacIntyre 1987, 187190) the abuser is loosing along with the whole community. Of course, such narratives can function ideologically in many ways. For instance, exaggerated attention to welfare abuse could reduce solidarity and security, the same internal goods the narrative claims to safeguard.

\section{Other Narratives of Moral Responsibility}

While the welfare abuse -narrative may be the best known social responsibility -narrative, it seems that there are other cases that fit with our model as well. When one looks at the writings ${ }^{1}$ or interviews ${ }^{2}$ of the unemployed themselves, the perhaps most often recurring complaint about the media and politicians is that they are implying that the unemployed are 'work-shy'. According to the complaints this is often done by using the rhetoric of the 'whip'. 'Whip' and 'carrot' are in Finland now commonly used as metaphors to describe two main ways of controlling the 'the donkey', i.e. the people. 'Whip', unlike 'carrot', refers to a kind of punishment - it implies some pain but not too much pain, pain to be used only as a means to a good end. 'Whip', unlike 'carrot', fits well in the social responsibility -narrative, because 'whip' can be used only to emphasise people what their responsibilities are. 'Whip' can be legitimately used only if people don't otherwise do what they ought to do. 'Carrot', on the other hand, involves reward: it is about making a deal, and thus entails acknowledging that people have a right to expect something in return - thus it invokes the idea of social right rather than that of responsibility.

To take an example of the narrative of 'whipping': The Final Report of the Government Committee on Incentive Traps (Kannustinloukkutyöryhmä 1996) takes as its starting point the following programmatic statement of the government: "The social security system is to be developed so that working will always improve one's economic situation". (ibid. 5). If working is not profitable, one is caught in an incentive trap. However, removing incentive traps entails reducing benefits. The report recognises this: "The need to improve the incentives to working is basically contradictory with the need to maintain high level of social security and low income differences." (ibid. 11). This recognition is 
transformed into something like a language of miracle cure in the following statement: "Improving the social security and taxation systems so, that incentives increase, entails a relative decrease in the level of living for those living on social security at least on the short run. On the longer run these goals don't have to be in contradiction with each other, because effective functioning of the labour market does help in improving the employment situation and those who will be employed in this way will also reach a higher income level than before." (ibid. 11, italics ours). Here the "whip' - worse benefits - is justified by a hopeful belief that more jobs will emerge and wages will be better than the previous higher benefits. Cutting benefits is represented as a cure to a complex of problems: unemployment, poverty, marginalisation, high social costs, functioning of the economy and the image of the welfare state in the eyes of the taxpayers. (ibid. $9-11$ ). The core assumption of the cure is that it motivates people to search for and accept jobs, that people will find them, and that the pay will be good enough. Each assumption can be questioned.

How is the miracle cure -story, then, narrated in public? The following excerpt shows it wrapped in the language of economists. The speaker, whose suggestion is summarised in the leading Finnish newspaper Helsingin Sanomat ("Niinistö puuttuisi ansiosidonnaiseen”. 1.8.2000), is Minister of Finance Sauli Niinistö.

Niinistö proposed on Monday, that unemployment benefit should be scaled so, that its level would be higher in the beginning of the unemployment period and would decrease below the current level towards the end of the 500 days period ... He believes that the proposed model would encourage people to become employed. The model would not, at least not at once, increase government costs ... New measures are, in his view, needed, because there are still so many unemployed in the country despite the economic growth. On the other hand, some sectors face labour shortage, and supporting job-searching would block higher wages and thus inflation ... Niinistö emphasised, that the country faces a risk of economic overheating, which is linked to insufficient supply of labour.

To further show why the story is close to the theme of social responsibility, we give another example. Here the speaker, conservative member of the European Parliament, PiaNoora Kauppi, is expressing her support to the suggestion of the Minister of Finance (quoted in newspaper Aamulehti 9.8.2000, "Muut lehdet").

The truth is, that jobs remain vacant because one cannot find workers out of these hundreds of thousands of unemployed. These jobs, that in vain wait for somebody to take them, are not only for well educated computer-nerds. There are also vacancies, that anyone who is healthy, adult and willing to work could fill. There are 30000 unemployed job-seekers in the capital area only, but strawberries nevertheless rot in their bushes in Nurmijärvi because one cannot get anybody to gather them.

The party that took a prominent public role in promoting the miracle cure of incentives was not originally the conservative coalition party but the social democrats, and primarily the Second Minister of Finance Arja Alho, the chair of the Committee on Incentive Traps. She had also to defend the government's policy in the parliament, which prompted the tabloid Ilta-Sanomat to print this headline on its front page (12.12.1996).

Minister Alho: The unemployed need also whipping 
The quotes show three slightly different attitudes to the theme of social responsibility. While the first avoids moralising the unemployed openly, it nevertheless individualises them. Cutting benefits is legitimised by implying that the unemployed could indeed find work if they just tried hard enough. The second is already openly accusing the unemployed. In the third, minister Alho seems to employ the third aspect of social responsibility -narrative mentioned above, the tendency to criticise the welfare state by implying that cutting benefits is good for the unemployed. The benefits are now construed as harmful (though the effect of the rhetoric is, of course, somewhat undermined by irony in the headline).

Narratives we have studied so far seem to be inclined to represent the unemployed in negative terms - via showing instances where social responsibilities are neglected. One would suppose, that positive narratives about the unemployed might be also found. To be neo-conservative such narratives ought still to emphasise the idea of social responsibility. This could be achieved through telling about those unemployed who have performed in an exemplary way. This exemplary way should be something more than can be expected from one who lives according to the standards of the Nordic welfare state, which is to be construed as 'bad life'. Thus, 'good life' would entail valuing 'something else' higher than the goods of the welfare state.

To take an example, when daily Aamulehti decided to publish a special section about (and for) the unemployed in 1993, the first "Unemployed's Page" had, as its main story, an interview of an unemployed bank cashier who had bought a small shop ("A At last I get to meet people again'", 21.2.1993). Workdays are long and the reader learns that the shopkeeper has managed to make 22000 marks during her first year, but: "One must want it so much that small troubles just don't bother at all.". In 28.3.1993 another headline states: "I want to work even if that cost me money". The story is about an unemployed stylist who takes a part time teaching job even though her unemployment benefits drop more than her salary brings her money. Besides being exemplary these characters problematise certain common views: e.g. that work is done mainly for money and that wage is a compensation for the pains of working. Instead, their stories imply, that work is good in itself and that not working is more painful than working. In the common view one weighs the pain of work against the wage and not working is simply leisure, while in the stories' calculus one weighs the pain of not working against the wage, and joy of working becomes part of the wage: thus it becomes reasonable to pay for the chance to work.

The official labour policy has in Finland increasingly emphasised the job-seekers' own initiative and responsibility in getting jobs (see Julkunen 2001, 177-184; Lehtonen $\&$ al. 2001 111-115). Ministry of Labour has ventured to use also media quite actively. A new territorial conquest has been a TV-show "Good Working” (Hyvää Työtä!), produced jointly by the public TV 2-channel and the Ministry of Labour. In the show three pre-chosen applicants are interviewed by a job-offering firm's personnel manager in the TV-studio. The program has two hosts: an ice-hockey -coach and management consultant - known for his appearances as a TV-commentator - and a representative of the labour administration. The show is acted out in front of a live audience consisting of the firm's other workers, the happy winner's future team-mates. The prize, of course, is the job, which is given to only one of the three. The show builds a curious atmosphere by bringing something very private into public and construing something rather serious as entertainment.

The TV-show aside, there has appeared a host of less chimerical news stories where the unemployed act as participants in different labour policy measures. Instead of pre- 
senting exemplary job-seekers, this kind of narrative appears to construe something as normal. Thus, the stories show what any unemployed are "normally" expected to do (be active, search for work) and how they are "normally" expected to present themselves in public (as job-seekers who hope to get help in searching for work). If one compares these representations of the "exemplary" with those of the "normal", one finds that both individualise the unemployed - either they are represented as ones who already have solved their problem or as ones being helped so that they could solve it. The moral indignation of earlier examples is transformed into praise or acceptance. What is avoided in such stories is making unemployment a political problem that requires political debate over possible solutions. Instead, the current policies are legitimised. Since these policies have come increasingly to emphasise individual responsibility, the stories legitimising them tend also to emphasise social responsibilities of the unemployed.

One characteristic difference between the "negative" stories and "positive" ones is, that the latter seem to require some kind of co-operation by the unemployed themselves. Typically some unemployed or applicants are brought to the public and interviewed. Politically these stories are, we suggest, ambiguous: people are not forced to say something they don't want to say - neither can one say that they are simply speaking their mind. While speaking for themselves, they are also talking to some audience, and must adapt to the moral standards, real or imagined, of that audience. In short, they must present themselves in an acceptable way. Therefore, there is a possibility that when brought before the public eye they feel compelled to produce accounts that fit with the hegemonic discourse. This means that though the survival strategies that are offered may well be plausible, they are, nevertheless, strategies acceptable for the hegemonic view. In the context of neo-conservative shift this would mean more and more emphasis on individuals' social responsibilities.

\section{Narrative Paradox and Absurdity of the Public Sphere}

We must set aside here the empirical question how far the different forms of individual responsibility -narratives have in fact acquired a hegemonic position in the welfare political news. Instead we try to assess their possible consequences. One thing that suggests the importance of such study is the critical assessment of the media, politics and policies, that is given by the unemployed themselves. The National Co-operation Organisation of the Unemployed (TVY) has criticised the attitude of the media towards both the unemployed and their organisation (see e.g. Oittinen 1997). The unemployed interviewed in Tampere in 1996 pointed out several problems already dealt with above. The perhaps most irritating feature in the media coverage was its moralising tone. Press wrote too little about unemployment, the coverage was superficial and the everyday experience of the unemployed was overlooked. The coverage tended to be unrealistic and presented a too nice picture of the issue. The unemployed were able to get their own views published only in the letters to the editor -section, which they themselves saw as a relatively marginal forum. (see also Ridell 2000). Similar critical assessments are found in the writings of the unemployed (see e.g. Laaksonen \& Piela 1993, Kortteinen \& Tuomikoski 1998). In these texts politicians and the media are often grouped together - either they are represented as co-operating or the media is represented as a neutral platform for the politicians. Both are often represented as inhuman and indifferent. In the special section "The Unemployeds' Page" published by Aamulehti in co-operation with the local unemployeds' association in Tampere in 1993 and 1994 the picture given of the authorities was 
also primarily critical. The unemployed described the official policies as a "symbol-jungle" doing its best to hinder their attempts to improve their situation. (Vehkalahti 2000).

Research findings lend some support to the complaints against individualisation and moralising. Welfare abuse, for its part, has been generally deemed as not a very important problem, unlike the 'tip of the iceberg' -rhetoric implies. One study estimates that abuse amounts to less than one per cent of the total sum of benefits even if the hidden part of abuse is taken into account (Heikkilä \& al 1999, 76). Neither does it seem likely, that the Finnish unemployed were simply lazy job-seekers - even the most active jobseekers have difficulties in finding work. According to one study, even though active job searching is conducive to employment, no more than 22-28 per cent of those who claimed to be among the most active did in fact have a job 11 months after they were interviewed. Of the somewhat less active, 13-17 per cent had found themselves a job during the same period. (Virjo \& Aho 2001). The results of the labour policy measures seem to have been somewhat disappointing (Aho \& al. 1999, Aho \& Kunttu 2001).

What is said so far suggests two comments. First, the individual's possibilities to influence his or her position in the labour market should not be overestimated, but the narratives described above tend to emphasise individual responsibility and raise suspicions. Second, the function of the public sphere should be to challenge such narratives if need be, but the practises of the mass-mediated public sphere tend to marginalise the voices of marginalised groups like the unemployed. This is partly due to the journalists' professional rules concerning who can be interviewed, what is publishable and newsworthy, what kind of action is acceptable etc. The proliferation of the narratives of social responsibility and the barring of the scapegoats from the public sphere could have, as their one possible practical consequence, a kind of absurd and closed public sphere. In the following we try to elaborate this claim a bit.

Moral narratives, first of all, tend to become paradoxical. This paradoxicality doesn't refer to the phenomenon that different audiences decode the same texts in different ways. Rather, a paradoxical narrative, as we understand it here, tends to press some of its readers to do something that for them seems to be impossible, irrational or unfair. This pressure is related to the moral indignation or praise expressed by the narrative. Moral narrative represents some groups or individuals in moral terms, as villains, victims and heroes. However, in order to become paradoxical, such a narrative has also to be able to put pressure on its reader. This can be done by trying to appeal to the reader and by warning him or her. A negative story about some group may cause its members to feel that they should either dissociate themselves from the group or defend it. In addition, the group-members know that the story has stigmatised them in the eyes of the outsiders, which serves to amplify the pressure. In both ways, by appealing and by warning, a moral narrative drives people toward imitating its heroes or victims and avoiding to act like the villains. In this way the narrative seems to function like a command: it gives directions for action and hints about possible consequences if these are not followed.

The moral narrative seen as a command is at the core of our concept of paradoxical narrative. If a narrative can be a command, it can also be a paradoxical command, the so called double bind. According to Bateson (1987) (see also Wilden 1980, Bordo 1993; Hellsten \& Renvall 1997) some communication may lead into a paradoxical situation, a double bind, and, furthermore, some paradoxical situations are pathological. The elements of a pathological double bind can be defined as follows (see Bateson 1987, 206207; also Wilden 1980, 120): 
1) In a double bind, there are two or several people, of whom one is "victim". ${ }^{3}$ The relationship between these people is unequal.

2) The victim constantly feels s/he is in this double bind. It is not an experience or a memory of a traumatic experience, but a learnt way of experiencing a situation.

3) In a double bind situation, there are two conflicting negative commands and a threat of punishment. These commands can be expressed as follows: a) do not act so and so, or you will be punished; b) if you do not act so and so, you will be punished

4) The second command is usually communicated in a metalevel, and is often given as a non-verbal clue.

5) There is also a third negative command which prevents a victim from breaking free from the double bind.

All these elements are not needed, when a victim has learnt to interpret his world through double binds.

It may be easier to grasp the idea of the double bind with the help of a simple example. The sentence "Don't read this sentence" is a double bind, a command one cannot obey. If one tries to obey one at the same time disobeys. However, it is not a pathological double bind for no punishment follows if it is not obeyed.

In the following quote an unemployed writer describes his experience of what we take as a paradoxical command issued through TV-news. The writer refers to the Minister of Labour Ilkka Kanerva who apparently has used the narrative of the 'whip' described above. The quote is taken from Kortteinen \& Tuomikoski $(1998,126)$ and belongs to the collection of stories by the unemployed referred to above. Two elements of the bind seem to be clearly discernible: the paradoxical command (to search for a job when there is none) and the feeling of helplessness (waiting in the train without the engine):

Kanerva pushed the knife ever deeper in this chest. Said that the unemployment benefits are to be scaled so that we'll get to the general European level while at the same time activating the unemployed to find jobs. What jobs, damn it? Where are they? Sure we'll soon be activated and take jobs by force from those who have them, if that's the only advice the Minister of Labour has to give. ... When you try and you become activated, you will be given ... Let your dick bloat so that you cannot walk or piss anymore. In your dying pains then you'll find out what it is to be on the side tracks of life, in a train that never moves anywhere. There one waits and no activating will pull the engineless train anywhere. It's a shame for you bastard to beat one who is already down.

The double commands of Kanerva's paradoxical narrative can be put roughly as follows: a) if you don't try to get 'active' you are 'not good'; b) if you try to get 'active' you nevertheless are 'not good'. The logic of Kanerva's argument, as it apparently was taken by the writer, goes as follows: if you are 'active' you'll find work - thus, however much you try, if you don't find work you never really were 'active'. Any attempt to be 'active' is transformed into a further evidence that one never was - or wanted to be - 'active'. This evidence justifies new incentives, new incentives cause further attempts to be 'active', these provide new evidence calling for new incentives and so on. The gist of this double bind is that, from the writer's point of view, minister Kanerva refuses to admit that for the writer there is no such 'activity' that would bring him work and would thus count 
as 'real activity'. Precisely by trying to obey Kanerva's command the writer would end up disobeying it.

Another concept of Bateson is also crucial here, that of metacommunication (see e.g. Wilden 1980,120-121). Metacommunication is communication about the way one should be communicating and it provides a way to transcend the double bind. The victim of the bind may escape it by explaining those who keep up the bind the paradoxical nature of their communication, and the participants could then negotiate new ways of communicating. In a pathological double bind the third command blocks this possibility, and the victim remains in the loop. Our quote from the unemployed writer can be seen as an attempt to metacommunicate: to lay bare the paradoxical nature of the minister's communication and perhaps even to try to change the patterns of communication between the minister and the unemployed. The violent style of the quote may describe the actual experience of the writer after watching the minister speak, but it might also be, that the writer has attempted to give as much force to his words as he is able to make himself heard somewhere.

We can deduce two questions concerning the nature of public life from the theory of the double bind. First, do the stories that the media circulates include paradoxical narratives like the one just described? Second, is the public sphere open to metacommunication, when someone feels s/he is caught in the double bind? As long as metacommunication is allowed, the public, in the sense of a reasonably discussing group, can emerge. We call the public sphere closed if it, for instance, refuses to represent subversive acts ${ }^{1}$ aiming at metacommunication or represents such acts only as simply condemnable, like as crimes, but avoids representing them as good or even possibly acceptable; or represents them as perhaps understandable but in that case always irrational; or, again, represents them in a way that leads nowhere, makes no difference. Closed public sphere tends, if we are right, to strengthen possible pathological double binds people are stuck with. It might also give rise to political attacks against all kinds of marginalised groups and subversive subcultures. If paradoxical narratives are circulated in the closed public sphere the result could be an absurd public sphere. In it impossible or irrational acts would be systematically represented as heroic, subversive acts as villainous and the victims made the focus of public suspicions.

If one accepts the claim that moral narratives have a tendency to become paradoxical, one might also suggest that the public sphere implied in such moral narratives resembles somewhat the absurd public sphere. Consider again the case of welfare abuse -narrative. As we already pointed out such a narrative tends to block dissenting voices out of the public sphere by accusing them of speaking for criminals and crime. There is also a double bind involved, for to avoid becoming a suspect of abuse one has to do better than not to abuse. One has to get work, which may be impossible.

In moral panic situations the features of the absurd public sphere are plainly visible: the proliferation of moral narratives causes fear and anger, provokes demands for immediate and strong actions and leads to the silencing of the dissident voices. However, moral panics may be only "local intensifications" (c.f. McRobbie 1994, 209) of an already existing, invisibly paradoxical public sphere. Moral panics are used in order to gain political support, but if the support already exists, the pattern of politics may turn out to be different. Stories and interviews of the unemployed contain descriptions of how the unemployed have to face, in everyday situations, the prejudices of the working, and how they themselves had held these prejudices before becoming unemployed. In such a situation nobody gains anything immediately if the paradoxes are brought to light. For the majority of the people such dissident voices would represent a threat to their beliefs. 
Thus, for the politicians, to speak for the marginalised would mean endangering one's public support. In the same way, for the journalists, giving voice to the marginalised might provoke an angry response from the majority of the readers. For the unemployed, on the other hand, speaking publicly would probably make little immediate difference politically, whereas the individual, personal risk could be immediate and considerable. In such a situation, everybody gains, at least on the short run, by keeping silent. On the long run, the unemployed, as a group, would probably suffer, because the paradoxes, as long as they have become constitutive elements of the majority view, tend to become constitutive elements of the public support for policies that shape the life of the unemployed.

\section{Conclusion}

We have, in this article, described four kind of narratives that emphasise social responsibilities of the unemployed by way of individualisation and moralising. Such narratives can also be used to criticise different social benefits and build support for cutting them. We pointed out, that if the marginalised groups such as the unemployed are unable to express their experiences in the public debate, such moral narratives run the risk of becoming paradoxical, which could lead to a closed and absurd public sphere. We have presented this argument as a primarily theoretical and hypothetical one. The empirical question as to how far the Finnish public sphere during the 90's resembled such a distorted public sphere is left open. To conclude, we try to point out some features that may be relevant in answering this question.

It seems, first, that the accounts of the unemployed themselves would seem to give some plausibility to our description. These accounts fit with the picture we have of the overall development of the Finnish welfare state: the social rights are gradually being weakened while social responsibilities are emphasised (see Hänninen 1998, Julkunen 2001, Lehtonen \& al. 2001). However, when the actual public debates were studied, it was found that the social responsibility -narratives were, to some extent at least, challenged by opposing narratives (e.g. Renvall \& Valtonen 1999, Renvall 2001). In some cases the press has worked hard to give the unemployed a chance to gain access to the public sphere (Vehkalahti 2000). Nevertheless, there is a possibility that even if the press had functioned as a "warning system" it may not have succeeded in functioning as an "amplifier", that is in thematising the problems in an influential way. In conclusion we point out two things that might support this interpretation.

\section{Notes}

1. The writings of the unemployed Finns were collected by the Finnish Literature Society (SKS) and the Educational Federation for Unions for Professional Employees (TJS) through a writing competition held in Spring 1993. 1200 texts were received, of which 33 were published in a book (Laaksonen \& Piela 1993). We have used here these published texts as well as quotations of some unpublished texts in Kortteinen (1998). Here, as well as in the interviews, we looked for segments of texts where the media were mentioned, in order to find out how the unemployed spoke about the media and what features of it they criticised.

2. The interviews were made in Fall 1996 in a suburb Hervanta in Tampere. Of 55 interviewees 13 were then unemployed and 8 were interviewed especially about how the press represented the unemployed. We have used here these 8 interviews. (see Ridell 2000).

3. The victim of a double bind should not be confused with the victim of a moral narrative here. 


\section{Sources}

Aho, Simo, Jukka Halme \& Jouko Nätti (1999) Tukityöllistämisen ja työvoimakoulutuksen kohdentuminen ja vaikuttavuus 1990-1996. [Targeting and Effectiveness of Labour Market Training and Subsidized Employment in 1990-1996] Studies in Labour policy 207. Helsinki: Ministry of Labour.

Aho, Simo \& Susanna Kunttu (2001) "Tukityöllistämisen ja ammatillisen työvoimakoulutuksen vaikuttavuus 1994-1997." [Effectiveness of Subsidized Employment and Labour Market Training in 1994-1997] In. Tehoavatko toimenpiteet? Studies in Labour policy 288. Helsinki: Ministry of Labour.

Bateson, Gregory (1987) Steps to an Ecology of Mind. Collected Essays in Anthropology, Psychiatry, Evolution and Epistemology. First published in 1972. N. J. Aronson. Northvale.

Bordo, Susan (1993) Unbearable Weight. Feminism, Western Culture and the Body. University of California Press. Berkeley.

Clarke, John \& Janet Newman (1997) The Managerial State. Power, Politics and Ideology in the Remaking of Social Welfare. Sage Publications: Lontoo, Thousand Oaks, New Delhi.

Esping-Andersen, Gösta (1990) The Three Worlds of Welfare Capitalism. Polity Press. Cambridge.

Esping-Andersen, Gösta (1999) Social Foundations of Postindustrial Economies. Oxford: Oxford University Press.

Golding, Peter and Sue Middleton (1982) Images of Welfare: Press and Public Attitudes to Poverty. Oxford: Martin Robertson.

Habermas, Jürgen (1996) Between Facts and Norms. Contributions to a Discourse Theory od Law and Democracy. Translated by William Rehg. Cambridge: Polity Press.

Hall, Stuart (1992) "Thatcherismi ja teoreetikot". [Thatcherism and the Theoreticians] In. Hall, Stuart: Kulttuurin ja politiikan murroksia. Vastapaino. Tampere.

Heikkilä, Matti, Anne Leppänen \& Tuukka Lahti (1999) "Viranomaisten tietoon tullut sosiaaliturvan väärinkäyttö". [Welfare Abuse Detected by the Authorities] In Hellsten, Katri \& Hannu Uusitalo (eds.) Näkökulmia sosiaaliturvan väärinkäyttöön. Stakes raportteja 245.

Hellsten, Iina \& Mika Renvall (1997) "Inside or Outside of Politics? Metaphor and Paradox in Journalism." Nordicom Review 2/97. (41 - 47).

Hänninen, Sakari (1998) “Is Finland Going Beyond the Age of Entitlement?”. In Hänninen (ed.): Displacement of Social Policies. SoPhi, Jyväskylä.

Julkunen, Raija (1993) "Onko se ohi nyt?”. [Is It Over Now?] In. Haapala, Pertti toim: Hyvinvointivaltio ja historian oikut. Työväen historian ja perinteen tutkimuksen seura, Tampere.

Julkunen, Raija (2001) Suunnanmuutos. 1990-luvun sosiaalipolittinen reformi Suomessa. [Change of Course. The 1990's Social Political Reform in Finland.] Tampere: Vastapaino.

Kortteinen, Matti \& Hannu Tuomikoski (1998) Työtön. Tutkimus pitkäaikaistyöttömien selviytymisestä. [The Unemployed. A Study of the Coping of the Long-Term Unemployed] Helsinki: Kustannusosakeyhtiö Tammi.

Laaksonen, Pekka \& Ulla Piela (eds.) (1993) Työttömän tarina. [The Unemployed's Story] Helsinki: SKS.

Lehtonen, Heikki, Simo Aho, Jarmo Peltola \& Mika Renvall (2001) "Did the Crisis Change the Welfare State in Finland?". In Kalela \& al. (eds.) Down from the heavens, Up from the Ashes. The Finnish Economic Crisis of the 1990s in the Light of Economic and Social Research. Helsinki: Government Institute of Economic Research, Publications 27:6.

McIntyre, Alasdair (1987) After Virtue. A Study in Moral Theory. Second edition. Duckworth. London.

McRobbie, Angela (1994) Postmodernism and Popular Culture. London \& New York: Routledge.

Oittinen, Hannu (1997) "Sensaatio, fakta vai loppukevennys?" [Sensation, Fact or a Humorous Conclusion] Journalisti 3/1997.

Pietilä, Veikko (1999) "Julkiso ja yleisö". [The Public and the Audience] Tiedotustutkimus 22/3.

Renvall, Mika \& Sanna Valtonen (1999) "Miten sosiaaliturvan väärinkäytöstä puhuttiin julkisuudessa?" [How the Welfare Abuse Was Talked about in Public?] In Hellsten, Katri \& Hannu Uusitalo eds. Näkökulmia sosiaaliturvan väärinkäyttöön. STAKES Reports 245.

Renvall, Mika (2001) "Työttömyysturvan porrastaminen: Työttömät NAIRUn jatkoksi?" [The Scaling of the Unemployment Benefits: Hanging the Unemployed on NAIRU?] Tiedotustutkimus 1/2001.

Ridell, Seija (2000) “Kuuliainen kuluttaja vai kiihkeä kansalainen?” [An Obedient Consumer or a Passionate Citizen?] In Kunelius, Risto \& Seija Ridell (eds.) Kaksi katsetta journalismiin. Tampere: University of Tampere, Department of Journalism and Mass Communication. Publications A 94, 79-180.

Roche, Maurice (1992) Rethinking Citizenship. Welfare, Ideology and Change in Modern Society. Polity Press. Cambridge. 
Vehkalahti, Pertti (2000) "Töihin vaikka omaksi tappioksi: Aamulehden "Työttömän sivun” julkisuus kriittisen diskurssianalyysin kohteena" [To Work Even If It Cost Me Money: A Critical Discourse Analysis of the "Unemployeds' Page" of Aamulehti] Tiedotustutkimus 4/2000.

Virjo, Ilkka \& Simo Aho (2001) "Työnhakuaktiivisuuteen vaikuttavat tekijät”. [Factors Affecting Job Search Activity] Finnish Labour Review 3/2001.

Wilden, Anthony (1980) System and Structure, Essays in Communication and Exchange. Lontoo: Tavistock. 